\title{
Revize kurikulárních dokumentů pro střední odborné školství
}

\author{
Olga Kofroñová
}

\begin{abstract}
Abstrakt: Přspèvek popisuje pripravované revize kurikulárních dokumentů středního odborného školství: uvádi problémy, které byly identifikovány ve vztahu k naplñováni jejich základnich funkci, a hlavni charakteristiky návrhu pojeti jejich revizi. Príspèvek dále predstavuje celkový rámec kurikulárnich dokumentů i návrhy na flexibilni usporádáni školnich vzdèlávacích programů s využitím vzdělávacich modulì.
\end{abstract}

Klíčová slova: kurikulárni dokumenty, rámcové vzdělávací programy, školní vzdèlávací programy.

\section{ÚvoD}

Střední odborné vzdělávání zahrnuje v ČR širokou škálu oborů vzdělání s výučním listem nebo s maturitní zkouškou, které připravují absolventy pro přímý vstup na trh práce i pro další studium. Stále se jedná o převažující typ středoškolského vzdělávání, kterým procházejí více než tř̌i čtvrtiny populačního ročníku. Nicméně jeho funkce se v současné době dost zásadně proměnila, jak v souvislosti s expanzí vysokoškolského vzdělávání, tak se změnami na trhu práce.

Lidé, kteří se chtějí uplatnit $\mathrm{v}$ budoucí ekonomice poháněné inovacemi, budou potřebovat jiné vědomosti, dovednosti a kompetence než $\mathrm{v}$ minulosti. Ekonomiky po celém světě staví na kreativitě, inovacích a spolupráci. Kvali- fikovaná zaměstnání se více zaměřují na řešení nestrukturovaných problémů a na efektivní analyzování informací. Kromě toho technika stále více nahrazuje manuální práci a vstupuje do většiny aspektů života i práce. V ekonomikách vyspělých zemí došlo v průběhu posledních 50 let $\mathrm{k}$ postupnému poklesu počtu zaměstnání, která vyžadují jen rutinní manuální a kognitivní kompetence, a naopak ke zvýšení počtu zaměstnání, která vyžadují nerutinní analytické a interpersonální kompetence (obr. 1). K těmto trendům přispívají mnohé vlivy, včetně zrychlování automatizace a digitalizace rutinní práce.

Vzhledem $\mathrm{k}$ této situaci se ukazuje jako velmi naléhavé přizpůsobit odborné vzdělávání uvedeným trendům tak, aby i nadále mohlo plnit své funkce. 


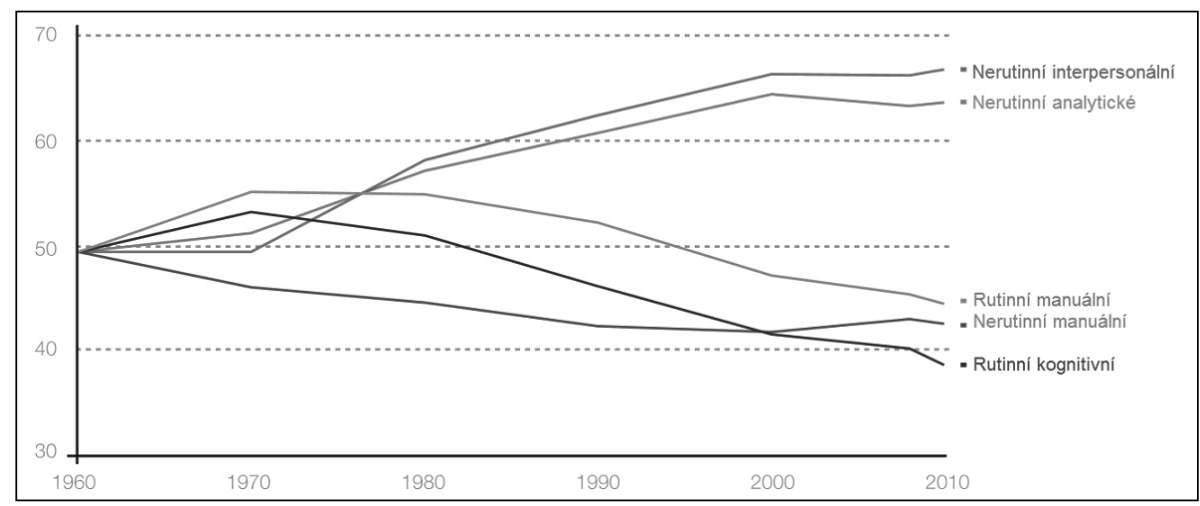

Obr. 1. Trh práce vyžaduje stále vyšší úroveň kompetencí. Úkoly podle percentilu v ekonomice USA v letech 1960-2009 (New Vision, 2015)

\section{PrinCIPY REVIZE RÁMCOVÝCH VZDĚLÁVACÍCH PROGRAMŮ (RVP) PRO STŘEDNÍ ODBORNÉ VZDĚLÁVÁNÍ}

Revize jsou založeny na podkladových analytických studiích pro jednotlivé skupiny oborů odborného vzdělávání, ${ }^{1}$ nicméně zcela chybí výzkumná šetření, resp. systematický monitoring, který by přinášel informace o dosavadním fungování rámcových vzdělávacích programů ve školské praxi.

Hlavní záměry revize vyplývají ze strategických dokumentů MŠMT (2014, 2015) a ve středním odborném vzdělávání sledují tyto hlavní principy:

- Prostupnost - vertikální i horizontální, bez slepých uliček; žák může kdykoli navázat na přerušené vzdělávání a pokračovat $\mathrm{k}$ získání vyššího stupně, včetně uznání předchozího učení.
- Flexibilita - diverzifikace vzdělávacích cest ve vztahu $\mathrm{k}$ různým možnostem uplatnění na trhu práce; flexibilní organizace výuky např. ve formě modularizace; flexibilní reakce na měnící se potřeby trhu práce.

- Kvalita - získané vzdělání dává předpoklady $\mathrm{k}$ celoživotnímu učení, zároveň umožňuje dobrou uplatnitelnost absolventů na trhu práce.

\section{LEPŠí ZÁKLADY PRO CELOŽIVOTNÍ} UČENÍ, ZVÝŠENÍ PROSTUPNOSTI

\section{A PREVENCE PŘEDČASNÝCH ODCHODŮ}

V současné době se žák musí v poměrně nízkém věku (15 let), již na počátku svého odborného vzdělávání, rozhodnout pro jeden z přibližně

\footnotetext{
${ }^{1}$ Dostupné z www.nuv.cz/t/studie-1.
} 
280 oborů $^{2}$ a má velmi omezenou možnost korekce své vzdělávací dráhy v průběhu studia, at již jde o stupeň vzdělání, nebo obor. Mnozí žáci z důvodu nedostatečných schopností nebo motivace nedokončí a předčasně opouštějí vybraný obor odborného vzdělávání, často několikrát začínají znovu studovat $v$ jiném oboru a jejich studium se prodlužuje a prodražuje (MŠMT, 2017).

Mnohé z oborů mají již od počátku úzký profesní profil, to znamená, že připravují žáky např́klad pouze pro jedno povolání, a tím omezují možnosti jejich uplatnění na trhu práce i př́padnou rekvalifikaci. Více než polovina absolventů nepracuje v oboru, který vystudovali, nedochází tak k očekávanému zúročení investic vložených do jejich odborného vzdělávání. Jak uvádí Strategie 2020 (MŠMT, 2014, s. 19): „Je třeba zajistit, aby nebyly finanční prostředky vynakládány na předčasnou profesní specializaci žáků, která v dlouhodobé perspektivě není a nemůže být smysluplně využitelná." Predikce vývoje potřeb trhu práce na dobu několika let trvání počátečního vzdělávání je přitom možná zpravidla pouze pro širší profesní oblasti, nikoli pro konkrétní obory.

Vzhledem $\mathrm{k}$ tomu $\mathrm{v}$ souladu $\mathrm{s}$ výše uvedenými strategickými materiály MŠMT navrhuje:
- posílit společný všeobecný a obecně odborný základ učiva $\mathrm{v}$ oblastech klíčových přenositelných kompetencí uplatnitelných zejména na trhu práce; všeobecný základ posilovat změnou jeho obsahu a relevance, nikoli změnou rozsahu;

- revidovat soustavu obori̊, resp. snížit počet oborů vzdělání tak, aby byla žákům umožněna postupná profesní volba a odsunuta brzká specializace.

Všeobecné vzdělávání je nedílnou složkou oborů odborného vzdělávání. Jeho celkový objem zůstane na současné úrovni, předpokládá se ovšem jeho modernizace. Bude posílen důraz především na základní gramotnosti (jazykovou, matematickou a digitální), jejichž dobré zvládnutí je předpokladem pro celoživotní učení. Ostatní vzdělávací oblasti budou revidovány tak, aby byl posílen jejich průpravný charakter vzhledem $\mathrm{k}$ odbornému vzdělávání.

Odborné vzdělávání bude koncipováno $s$ důrazem na širší odborný základ (technický, ekonomický, chemicko-biologický apod.) a užší odborný základ zpravidla pro danou skupinu oborů (např. stavební). Tím dojde i ke snížení celkového počtu oborů vzdělání.

\footnotetext{
${ }^{2}$ Rámcové vzdělávací programy středního odborného vzdělávání byly vytvářeny postupně od roku 2007 do roku 2012. Pro každý obor vzdělání uvedený v nařízení vlády o soustavě oborů vzdělání v základním, středním a vyšším odborném vzdělávání vydalo Ministerstvo školství, mládeže a tělovýchovy samostatný RVP. Celkem bylo vydáno 281 RVP v těchto termínech:

1. vlna (červen 2007): školy podle nich učí od 1. zárí 2009;

2. vlna (květen 2008): školy podle nich učí od 1. záŕí 2010;

3. vlna (květen 2009): školy podle nich učí od 1. záŕí 2011;

4. vlna (duben 2010): školy podle nich učí od 1. záŕi 2012;

5. vlna (červenec 2012): školy podle nich učí od 1. zárí 2014;

6. vlna (listopad 2012): školy podle nich učí od 1. záŕí 2015.
} 
Rámcový vzdělávací program (dále jen RVP) obori vzdélání s odborným výcvikem (kategorie E, H, L0) bude konstruován jako široce profilovaný větvený obor s možností ukončit studium po 2., 3 . a 4. ročníku. Pro školu to bude znamenat možnost vytvořit svůj školní vzdělávací program (ك̌VP) pro dvouleté, tř́leté nebo čtyřleté obory, popř. pro všechny uvedené úrovně oboru či jejich kombinace. Pro žáky to znamená možnost různých vzdělávacích drah. Tento př́stup ke konstrukci RVP/ŠVP by měl žákům umožnit dosáhnout maxima podle jejich schopností a motivace. Úspěšné ukončení studia zvolené úrovně a odborného zaměření povede k získání certifikátu - výučního listu, resp. maturitní zkoušky. ${ }^{3}$

Pro skupiny obori vzdèláni kategorie $M s$ maturitni zkouškou budou vytvořeny také rámcové vzdělávací programy se společným odborným základem. Stále více absolventů těchto oborů pokračuje ve studiu na terciární úrovni, vzhledem $\mathrm{k}$ tomu je možné vedle oborů s jasným profesním profilem ve větší míře koncipovat obecně odborné studium „lyceálního" typu.

Současné obory vzděláni kategorie L5, tzv. nástavbové obory, budou z důvodu vysokého podílu předčasných odchodů žáků z tohoto typu vzdělávání omezeny pouze na několik oborů.

Pro absolventy oborů s výučním listem bude jako další možnost zvýšení odborné kvalifikace koncipována mistrov- ská zkouška, kterou bude možné složit až po získání stanovené praxe.

Tyto záměry vyžadují následující systémové změny:

- uvolnit přístup do oborů vzdělání kategorie E i žákům, kteří nemají uznané speciální vzdělávací potřeby;

- nově koncipovat profilující část maturity pro žáky oborů L0 a M;

- koncipovat mistrovskou zkoušku jako vyšší profesní certifikát (EQF 5) pro absolventy oborů $s$ odborným výcvikem.

\section{USNADNĚNÍ PŘECHODU}

\section{ABSOLVENTU゚ NA TRH PRÁCE}

V současné době je každý obor vymezen př́islušným RVP pro celé období vzdělávání (tj. až čtyři roky), což musí respektovat i školní vzdělávací programy. Požadavky zaměstnavatelů na kompetence absolventů se mění rychleji, než je cyklus změn rámcových vzdělávacích programů, stejně tak se rychle proměňují potřeby trhu práce.

Zatímco RVP by měl být i nadále stabilnější dokument obsahující odborný základ, flexibilní složku by řešilo propojení s profesními kvalifikacemi národní soustavy kvalifikací (dále jen NSK), která ze své podstaty pružněji reaguje na potřeby trhu práce i dynamiku změn technologií.

Vzhledem k tomu se navrhuje propojit RVP s kvalifikačními a hodnoticími standardy NSK, a tím i počáteční vzdělávánís měnícími se potřebami trhu práce.

\footnotetext{
$\overline{3}$ Pro specifické obory, ve kterých se nepodaří funkční společný odborný základ vyčlenit, budou i nadále připravovány samostatné RVP.
} 


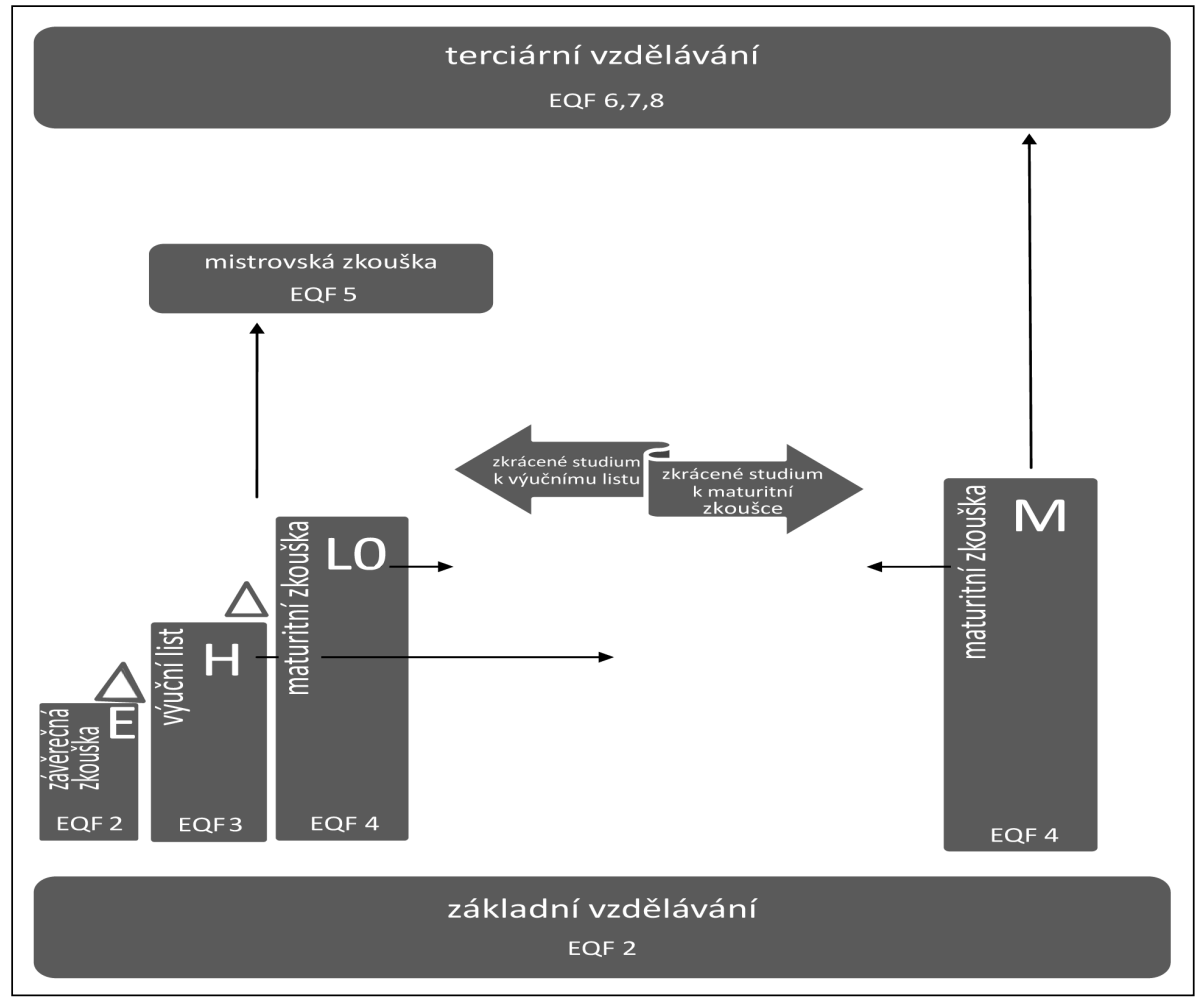

Obr. 2. Schéma výstupů odborného vzdělávání

Národní soustava kvalifikací disponuje relativně flexibilním systémem návrhu a schvalování profesních kvalifikací. Sektorové rady, nezávislá a zaměstnavateli organizovaná sdružení odborníků, analyzují profesní a kvalifikační potřeby v sektoru, navrhují strukturu kvalifikací a vytvářejí kvalifikační a hodnoticí standardy jednotlivých profesních kvalifikací. Dosud byly profesní kvalifikace primárně určené pouze pro certifikaci výsledků dalšího vzdělávání, cílem však bylo jejich následné využití $\mathrm{v}$ počátečním odborném vzdělávání. Důvodem k tomu je zvýšení relevance počátečního vzdělávání $\mathrm{k}$ potřebám zaměstnavatelů, a tedy zvýšení uplatnitelnosti absolventů. Využívání synergií počátečního odborného vzdělávání a NSK by dále přispělo ke zvýšení atraktivity odborného vzdělávání např. možností získat doplňkové kvalifikace požadované zaměstnavateli. $V$ neposlední řadě by usnadnilo situaci žákům neúspěšným u závěrečných nebo maturitních zkoušek 


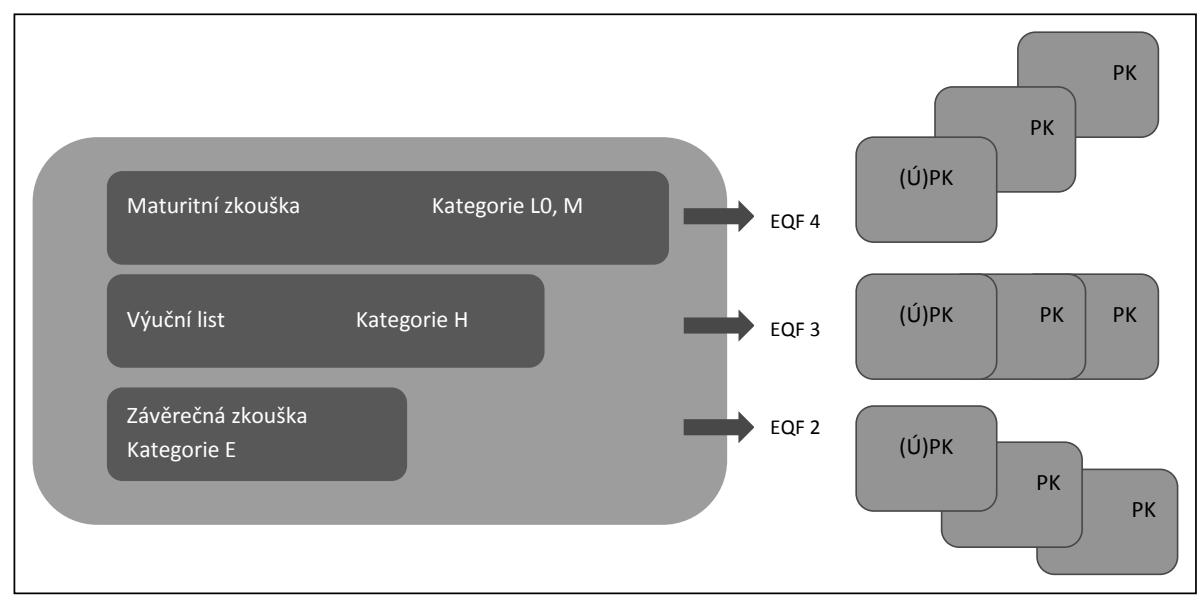

Obr. 3. Propojení RVP/ŠVP s profesními kvalifikacemi (ÚPK - úplná profesní kvalifikace, PK - profesní kvalifikace)

tím, že by byli připraveni získat alespoň profesní kvalifikaci uplatnitelnou na trhu práce.

RVP bude svázán $s$ konkrétními profesními kvalifikacemi volně, tzn. že nově vznikající nebo novelizované profesní kvalifikace budou moci být přiřazovány $\mathrm{k} R V P$, aniž by se nějak měnil. K RVP se širokým odborným základem bude přiřazeno zpravidla více profesních kvalifikací a teprve škola rozhodne podle svých podmínek, spolupráce se zaměstanavateli a zájmu žáků, kterou zapracuje do svého školního vzdělávacího programu. Zatímco životnost RVP se předpokládá $\mathrm{v}$ horizontu střednědobém (5-10 let), životnost profesních kvalifikací může být $\mathrm{v}$ př́ípadě rychle se rozvíjejících sektorů hospodáŕství výrazně kratší (1-2 roky). Průběžné přiřazování profesních kvalifikací tak umožní udržet počáteční odborné vzdělávání relevantní k potřebám trhu práce.
Vzdělávání bude i nadále ukončováno závěrečnou, resp. maturitní zkouškou, po jejímž úspěšném složení žák získá výuční list, resp. vysvědčení o maturitní zkoušce pro daný obor vzdělání, a kvalifikaci, která bude uvedena ve školním vzdělávacím programu.

\section{FleXIbILNÍ ORGANIZAČNí USPOŘÁDÁNÍ ŠKOLNÍCH VZDĚLÁ- VACÍCH PROGRAMŮ (VÝUKY) JAKO PŘEDPOKLAD REALIZACE ODBOR- NÉHO VÝCVIKU / ODBORNÉ PRAXE U ZAMĚSTNAVATELU゚}

Vzhledem k rigidnímu organizačnímu uspořádání školní výuky (pevný týdenní rozvrh hodin, týdenní střídání odborného výcviku a odborné teorie, pevně vymezený školní rok, prázdniny apod.) nemohou školy vyjít vstříc potřebám odborného výcviku 
a odborné praxe u zaměstnavatelů. Ti většinou požadují větší časovou koncentraci, roli hrají např. i sezonní práce. Flexibilní organizační uspořádání výuky by umožnilo sbližit možnosti pracovního a školního prostředí, a byly by tak vytvořeny předpoklady pro realizaci odborného výcviku a odborné praxe u zaměstnavatelů i pro snadněǰsí účast odborníků z praxe ve výuce.

Vzhledem ke snižujícímu se počtu vzdělávaných $\mathrm{v}$ odborném školství a větší roztříšstěnosti oborové struktury $\mathrm{v}$ jednotlivých školách je také nutné, aby RVP/ŠVP umožnily školám organizovat výuku pro menší skupiny žáků, kteří si zvolí různé výstupní kvalifikace, tzn. vyučovat vedle tradičních tříd i v multioborových tř́dách nebo vyučovat tzv. malotřídně, tj. různé skupiny žáků různému obsahu v jedné tř́iě.

$\mathrm{K}$ tomu by mělo přispět uspořádání výuky na základě vzdělávacích modulů, které se v současné době připravují v rámci projektu Modernizace odborného vzdělávání (NÚV, 2018).

Vzdělávací modul je chápán jako vymezení relativně ucelené části vzdělávání, která musí splňovat některá základní kritéria (NÚV, 2017):

a) mít svou vlastní specifikovanou funkci a jasně definované očekávané výsledky učení;

b) definovat (charakterizovat) určitý soubor učebních situací, učebních činností, učební látky;

c) být schopna zapojení do rozmanitých vzdělávacích cest či směrů studia.

Poslední uvedená charakteristika modulu je nejpodstatnějšś. Odlišuje modul např. od učební osnovy vyučovacího předmětu. Učební osnovy jsou koncipovány $\mathrm{z}$ hlediska zvládnutí určitého vzdělávacího oboru, tj. jsou určeny $\mathrm{k}$ začlenění převážně do jediné předem známé struktury tohoto oboru. Modul by měl na rozdíl od nich existovat relativně nezávisle. Je nutno ho chápat nikoli jako prvek jediné a jasně definované struktury, ale ve vztahu $\mathrm{k}$ různým kontextům a vzdělávacím cestám, kde může najít široké uplatnění.

Vzhledem $\mathrm{k}$ tomu je velice důležité jasné definování výsledků učení, kterých mají dosáhnout žáci absolvováním modulu. Je to důležité nejen z hlediska výuky, ale zejména proto, aby se objasnilo, jak a čím konkrétní modul může přispět celému výchovně-vzdělávacímu procesu.

Vzdělávací moduly tvoří tedy prvky určité „stavebnice“ a tím významně rozšiřují možnosti flexibilního uspořádání vzdělávacích programů.

\section{ZÁVĚREM}

Revidované kurikulární dokumenty pro odborné vzdělávání by tedy měly mít podobu tzv. kompetenční pyramidy, jejiž základnu tvoří všeobecné vzdělávání a klíčové kompetence jako předpoklad pro celoživotní učení a na jejímž vrcholu je konkrétní kvalifikace, kterou by měl žák získat na základě spolupráce školy a konkrétního zaměstnavatele.

Poznámka: Předložený text byl již autorkou publikován v obměněné podobě ve Zpravodaji oborových skupin (č. 15, podzim 2017), který vydává NÚV pro potřeby svých externích spolupracovníků. 


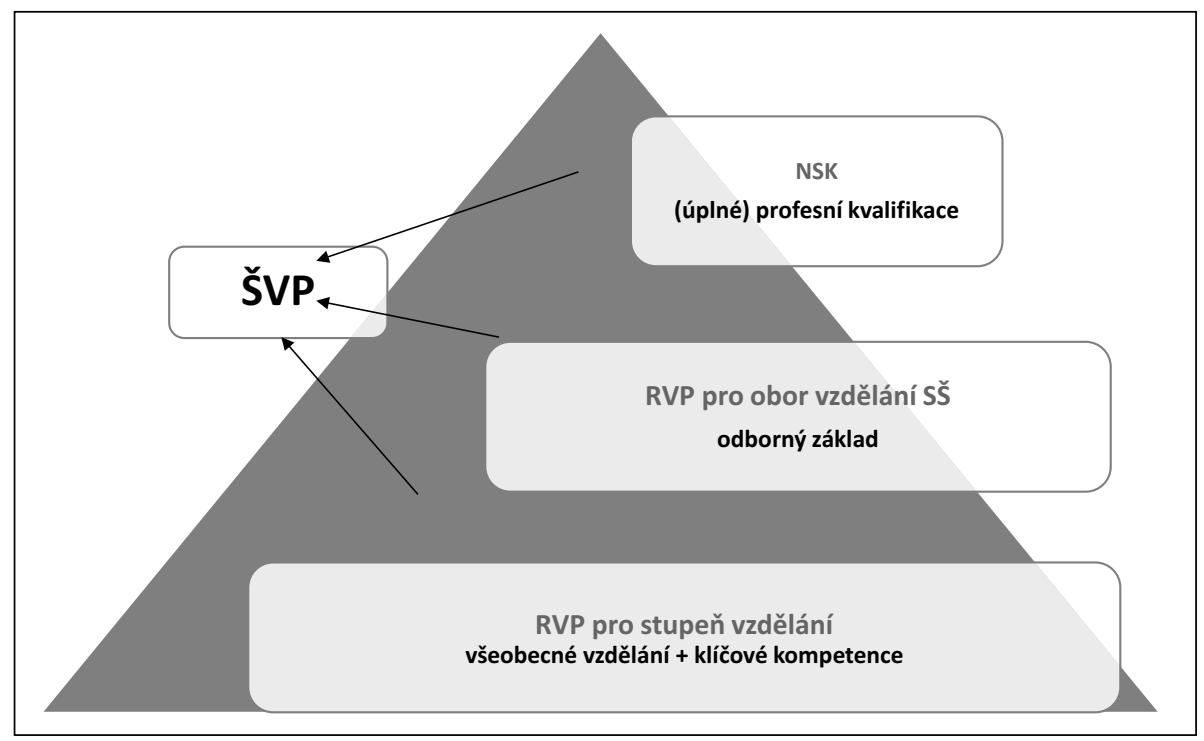

Obr. 4. Schéma celkového uspořádání kurikulárních dokumentů pro obor odborného vzdělání tzv. kompetenční pyramida (Revize NSK probíhá permanentně podle potřb trhu práce. RVP pro obor vzděláni budou revidovány častěji - v horizontu 5-10 let. RVP pro stupeñ vzdèláni budou relativně nejstabilnèjši - revize v horizontu 10-15 let.)

\section{Literatura}

MŠMT (2014). Strategie vzdělávací politiky ČR do roku 2020. Praha: MŠMT.

MŠMT (2015). Dlouhodobý zámér vzděláváni a rozvoje vzdělávaci soustavy ČR na obdobi 2015-2020. Praha: MŠMT.

MŠMT (2017). Návrhy opatřeni $k$ omezeni predčasných odchodů ze vzdělávání. Materiál pro poradu vedeni MŠMT. Praha: MŠMT.

New Vision (2015). New Vision for Education - Unlocking the Potential of Technology. Worlds

Economic Forum. (Online). Dostupné z https://www.bcg.com.

NÚV (2017). Připravujeme revize pro odborné vzdělávání. Zpravodaj Oborové skupiny, 15.

NÚV (2018). Zpravodaj o modernizaci odborného vzděláváni. Praha: NÚV.

PhDr. Olga Kofroňová, Ph.D.

Národni ústav pro vzděláváni, e-mail: olga.kofronova@nuv.cz 
KOFROŇOVÁ, O. The Revision of Curricular Documents for the Middle (Secondary) Vocational Education System

The article describes the current revision of the curricular documents of middle (secondary) vocational education. It presents problems that have been identified in the fulfilment of their basic functions, and the main characteristics of the draft plan for their revision approved in 2017 by the Ministry of Education. The article also presents the overall framework of curricular documents and proposals for the flexible organisation of school educational programmes through the use of educational modules.

Keywords: curricular documents, framework education programmes, school education programmes. 